\title{
"Funding acquisition drivers for new venture firms: Diminishing value of human capital signals in early rounds of funding"
}

\begin{tabular}{|c|c|}
\hline AUTHORS & $\begin{array}{l}\text { Snehal Shetty iD https://orcid.org/0000-0002-5130-6283 } \\
\text { R http://www.researcherid.com/rid/C-7340-2019 } \\
\text { Ranjany Sundaram id https://orcid.org/0000-0003-0884-944X } \\
\text { R http://www.researcherid.com/rid/C-7347-2019 }\end{array}$ \\
\hline ARTICLE INFO & $\begin{array}{l}\text { Snehal Shetty and Ranjany Sundaram (2019). Funding acquisition drivers for } \\
\text { new venture firms: Diminishing value of human capital signals in early rounds of } \\
\text { funding. Problems and Perspectives in Management, 17(1), 78-94. } \\
\text { doi:10.21511/ppm.17(1).2019.08 }\end{array}$ \\
\hline DOI & http://dx.doi.org/10.21511/ppm.17(1).2019.08 \\
\hline RELEASED ON & Friday, 15 February 2019 \\
\hline RECEIVED ON & Monday, 24 December 2018 \\
\hline ACCEPTED ON & Friday, 01 February 2019 \\
\hline LICENSE & $\begin{array}{l}(\mathrm{cc}) \mathbf{E Y} \\
\text { This work is licensed under a Creative Commons Attribution } 4.0 \text { International } \\
\text { License }\end{array}$ \\
\hline JOURNAL & "Problems and Perspectives in Management" \\
\hline ISSN PRINT & $1727-7051$ \\
\hline ISSN ONLINE & $1810-5467$ \\
\hline PUBLISHER & LLC "Consulting Publishing Company "Business Perspectives" \\
\hline FOUNDER & LLC "Consulting Publishing Company "Business Perspectives" \\
\hline
\end{tabular}

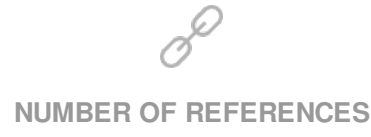

50

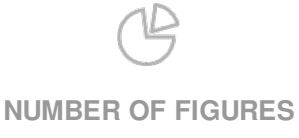

6

\section{= $=$}

NUMBER OF TABLES

8

(C) The author(s) 2021. This publication is an open access article. 


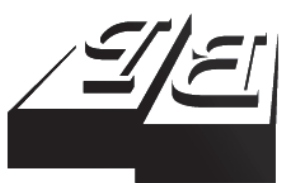

BUSINESS PERSPECTIVES

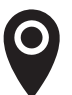

LLC "CPC "Business Perspectives" Hryhorii Skovoroda lane, 10, Sumy, 40022, Ukraine

www.businessperspectives.org

Received on: $24^{\text {th }}$ of December, 2018 Accepted on: $1^{\text {st }}$ of February, 2019

(C) Snehal Shetty,

Ranjany Sundaram, 2019

Snehal Shetty, MBA, Assistant Professor, Amrita Vishwa

Vidyapeetham, Kollam, India.

Ranjany Sundaram, BE, Assistant Professor, Amrita Vishwa Vidyapeetham, Kollam, India.

\section{(ㄷ)(ㄱ)}

This is an Open Access article, distributed under the terms of the Creative Commons Attribution 4.0 International license, which permits unrestricted re-use, distribution, and reproduction in any medium, provided the original work is properly cited.

\section{FUNDING ACQUISITION DRIVERS FOR NEW VENTURE FIRMS: DIMINISHING VALUE OF HUMAN CAPITAL SIGNALS IN EARLY ROUNDS OF FUNDING}

\begin{abstract}
Multiple factors such as human capital, amount raised in the first round, innovation etc. have an impact on the funding prospect of new ventures. This paper explored the influencing factors that drive multiple rounds of funding for new venture firms and provided a much broader perspective of funding drivers during the early stages of the new venture firm. Using signalling theory and human capital theory, this paper analyzed signals that influence the acquisition of funds in the first round and whether those signals persisted for the second and third rounds of funding when information asymmetries between the investors and new venture firms reduce. This study disentangled the signalling effects of the human capital factors across three funding rounds and proved the diminishing value of signals across each subsequent round of funding. Finding showed that the signal effect from premier institution education was the only human capital signal that persisted across each round of funding, while other signals did not persist beyond the first round of funding. In addition, new venture firms with founders educated from premier educational institutions were able to attract more in vestors and close more funding rounds. This study also proved that the amount raised in the first round of funding positively impacted the amounts raised in the second and third rounds stressing its importance for new venture firms. Empirical demonstration of the propositions was done with 156 new venture firms in India, the fastest growing and third largest startup ecosystem in the world.
\end{abstract}

Keywords

entrepreneur, signaling theory, funding, human capital, startups, India

JEL Classification M13

\section{INTRODUCTION}

Funding is a multi-stage process. The characteristics of the venture at the early stage are very different from that of a venture during the growth stage or Initial Public Offering (IPO). The venture undergoes a transformation as it evolves and obtains external financing, acquires customers and grows in terms of revenues and employees. Existing literature on entrepreneurship explored the relationships among the various human capital factors and the funding received by new ventures at a single stage/round (Klotz et al., 2014; Zimmerman, 2008). Past research only looked at funding as a one-time event (Baum \& Silverman, 2004; Zimmerman, 2008).

This study argued the importance of analyzing funding over multiple stages and not just at one stage as demonstrated by existing literature. Using signaling theory, this study disentangled the effects of the various human capital factors not only over the first round of funding, but also over three rounds of funding. 
An important contribution of this study was the exploration of two key aspects: signaling theory applied to the firms that received the first round of funding and the assessment of the diminishing impact of those signals over three rounds of funding.

The signals provided by the firm during the early stage will be different from signals provided by the same firm during the growth stage and IPO stage. Signaling theory is fundamentally concerned with the reduction of information asymmetries between the founders of the new ventures and the investors at the financing firms (Connelly et al., 2011). The investors evaluate the various characteristics of the new ventures by interpreting the signals sent by the founders and the various attributes of the firm (Zimmerman, 2008). Some of the signals that were influential at the time of the first round of funding could have diminishing value or no value during the later rounds of funding, as investors look for other cues such as financials, customers, sales growth, etc.

Past studies failed to analyze the importance of the amount of funding received in the first round and if that could act as a signal to future investors (Klotz et al., 2014; Zimmerman, 2008). Further, the quality of education and its impact as the signaling mechanism were not analyzed in the existing literature (Hsu, 2007; Klotz et al., 2014).

Linking human capital theory with signaling theory, this paper extended the research by providing contribution to new ventures in three distinct ways. First, this being one of the first studies in evaluating the diminishing effect and the persistence/non-persistence of human capital signals over multiple rounds of funding, this paper explored the various signals influencing the investments raised across each round of funding and human capital signals in-depth across multiple rounds of funding.

Second, the existing research analyzed either the education level or years of education (Hsu, 2007; Colombo \& Grilli, 2007) of new venture firm founders, but did not analyze the signal emanated from the quality of education as obtained from premier institutions by these founders. Important contribution of this paper is introducing a new quality dimension for education, which is graduation from a premier institution and measuring its signal impact over multiple rounds of funding.

Third, this paper explicitly analyzed the effect and influence of the signal from the amount raised in the first round of funding and its impact on subsequent two rounds of funding. This is an essential indicator to new venture firms, as it highlights the importance of the amount of funding raised in the first round irrespective of the need.

From 2010 to 2015, the period of this study, investments from local and international investors in new venture firms in India grew at an unprecedented rate making India the third largest and one of the fastest growing startup ecosystems in the world (Thorton \& Assocham, 2016), hence highlighting the timeliness of this study. Both fast emerging startup ecosystems and mature ecosystems will benefit from unique insights provided in this paper.

Next section deals with the literature review and hypotheses development followed by methods section and then concludes with explanation of results followed by discussion, implications and limitations of this study. 


\section{LITERATURE REVIEW}

\subsection{Signaling theory for funding acquisition}

New ventures face difficult founding conditions and face a gargantuan task of building and scaling their firms (Stinchcombe, 1965). Funding is an important pillar of resource acquisition and is one of the most important constituents that sustains and helps a new venture during the initial and future growth stages (Cooper et al., 1994). Raising funds for one's venture is a prolonged and arduous process (Rédis, 2010). This is due to information asymmetries between the founder and the investor (Connelly et al., 2011). Signaling theory is based on the foundation of reducing information asymmetries between two parties (Connelly et al., 2011). The new venture teams signal their latent potential and attempt to reduce this asymmetry by reducing the level of uncertainty about the venture (Higgins \& Gulati, 2006). Extant literature though dealt with the various signaling factors that contribute to sales growth, profitability, venture exits (Cooper et al., 1994; Klotz et al., 2014) is still short on analyzing the impact of the various signals on funding. The limited research on funding was skewed toward IPO exit stage of the venture and this does not hold much value as information asymmetries are significantly lower (Higgins \& Gulati, 2006).

\subsection{Human capital factors affecting funding acquisition}

Human capital theory relies on the premise of the capabilities of the founders involved in a new venture firm. Since the new venture has many uncertainties associated with it, investors look for things that are more certain about the firm. From this perspective, past industry experience provides a guiding post for future performance of the new venture. In a study across multiple industries in the Silicon Valley, it was found that the prominence of prior employers of founding team members increased the likelihood of obtaining external investment (Burton et al., 2002). Investors favored teams with strong expertise in the industry, social ties with important stakeholders and management experience in leading an organization (Zimmerman, 2008). However, other stud- ies found negative correlation between industry experience and attraction of investors because of founders' resistance to advice (Barney et al., 1996).

Investors preferred founders with good education (Zimmerman, 2008). However, other studies such as Amason et al. (2006) found no direct relationship between education (level, specialization etc.) and firm performance. This difference in view of past studies is due to the characteristic of the education variable-level versus quality of education obtained.

Prior startup experience, considered an important signal for future investors, gives a way for investors to assess the founders' capabilities and performance in similar situations (Hsu, 2007). Experiential learning and exposure to investors associated with previous firm should aid in raising funds for the current firm (Reuber, 1994). However, Cassar (2014) found no significant evidence linking prior startup experience and performance of firms.

It is vital to assess the signaling mechanisms of the various human capital factors and their influence in raising the first round of funding to have a clearer understanding of the possible gaps in literature. Argument which is put forth in this paper is that human capital factors are more important only during the first round of funding and their significance will reduce during the later stages of funding, as investors look for other signals during these stages. The persistence of the human capital factors decreases or has no impact in the later stages.

\subsubsection{Premier institution}

Formal education is considered an added advantage and it has direct influence on the prospects of the firm and the valuation at IPO (Zimmerman, 2008). But, Amason et al. (2006) have found conflicting results between performance and education. Because existing studies on signaling theory have looked at education from the perspective of the level and number of years of education obtained, they found no relationship between performance and education. A typical coding format has been used in these studies coding each echelon of education obtained. 
The existing literature on signaling mechanism for education variable has not measured the quality of education, even though Becker (1993) found that individuals with better degree credentials convey information about differences in abilities, persistence and other important traits. Quality of education mattered and CEOs that graduated from the top-20 US universities were able to realize superior performance (King et al., 2016). A more indepth view of the quality of education measured by the influence of premier educational institutions is necessary.

In the United States, the Ivy League schools are considered premier educational institutions of the country (Clement, 1975; Tapper, 2009). In India, Indian Institute of Technology (IIT) and Indian Institute of Management (IIM) are considered premier educational institutions and have highly restrictive entries and only highly talented candidates can secure admissions into these institutions (Subramanian, 2015; Henry \& Ferry, 2017). The first startup business incubators were set up in these institutions (Krishna \& Chandra, 2011). Many media articles with statistical backing have shown that founders graduating from premier institutions such as IITs and IIMs have been successful at raising more funding.

These schools also act as a breeding ground for strong social networks with deep connections within the industry and investor circles (Miller et al., 2015). It is not surprising that many celebrated CEOs have strong linkages to the premier institutions as many of them are graduates from these institutions (Miller et al., 2015). Graduates of premier institutions hence have the entry route to the inner sanctums of the key capitalist institutions (Tapper, 2009). Along the same lines, Maidique (1985) found that founders from high quality institutions have a positive influence on the success of their firms.

In an increasingly global workplace, continuing the education in other countries may give greater global awareness and engagement, openness to a variety of perspectives on international and cultural issues, and many other things that will enable students to form human capital after graduation (Paige et al., 2010). Studying abroad may allow students to form human capital in ways not possible at home and may enable them to earn higher incomes (Schmidt \& Pardo, 2017). Studying abroad and hence gaining the requisite human capital has been considered factors for premier institute education.

\subsubsection{Industry experience}

Entrepreneurship entails working with unfamiliar issues and situations that carry a high amount of risk as the outcomes could vary (Kirzner, 1997). Specific knowledge of the industry helps mitigate some of the risk by reducing the level of uncertainty related to industry (Baum \& Silverman, 2004). Industry experience increases the founder's exposure to current trends in the industry and reduces technology uncertainty (Delmar \& Shane, 2006).

\subsubsection{Prior startup experience}

Building a product or service and taking it to the market requires a different level of knowledge set that cannot be gained by working in an industry. The founder needs to overcome uncertainty by experimentation (Hsu, 2007). The knowledge gained through this effort is highly invaluable and these experiences greatly benefit the founder for future startup endeavors. Experiential learning gained through the effort of creating a venture and acquiring requisite expertise holds far more value that translates to performance of firm (Reuber, 1994). They may have raised funds for their prior startups and would have built connections with the various investors (Stuart et al., 1999).

\subsubsection{Founder's count}

Likeminded individuals who have worked as employees in large organizations found new venture firms and this leads to better cohesion of the team at least during the initial years. Due to the cohesivity, the founders engage in activities with the same view and choose the best course of action of the firm (Klepper, 2001). In fact, new venture firms with multiple founders provide signals to investors about the quality and more human capital leads to greater capital accumulations (Certo, 2003).

The abovementioned human capital factors should have the greatest influence on the first round of 
funding. This study posits that the signals emitted by the four human capital factors mentioned above should positively influence the amount raised in the first funding round. Therefore,

H1a: Education from a premier institution positively influences the amount raised in the first round of funding.

H1b: The more the industry experience, the more the amount raised in the first round of funding.

H1c: Founders with prior startup experience can raise more funds in the first round of funding.

H1d: The more the number of the founders, the more the amount raised in the first round of funding.

\subsection{Persistence of signaling over subsequent rounds of funding}

Existing literature failed to analyze signaling over multiple rounds of funding leading to a gap in current literature (Baum \& Silverman, 2004; Zimmerman, 2008). Funding is rather a continuous process, as firms need not just the first round of funding, but also a continuous flow of capital during their lifecycle to meet their needs for scale and growth (Colombo \& Grilli, 2007). This paper analyzed startups that received the first round of funding and further examined the effects of the various signals that were pertinent and important during the first round and their validity and strength beyond the first round of funding.

The proposition is that the signaling influence from most of the human capital factors should diminish as the startup progresses on its journey and moves beyond the first round of funding to the subsequent funding rounds. The only human capital factor that should significantly affect the future rounds of funding should be the premier institute education due to two reasons. Firstly, founders graduating from premier institutions would have higher quality of education and would be more innovative in nature (Marvel \& Lumpkin, 2007). The quality of education gained should help in building significantly better innovative products and processes that will provide multi- ple unfair advantages (Marvel \& Lumpkin, 2007). Secondly, founders from premier institutions have strong social networks that extend within the investor communities (Miller et al., 2015). A strong social network enables required connections to future investors.

H2: The signal emanating from premier institution will persist across subsequent rounds of funding. However, the signaling effects of other human capital factors reduce in each subsequent round thereby lowering the influence on the likelihood of funding closure in each respective round.

H3: Startups with founders from premier institutions can raise more amount of funds in $f u-$ ture rounds of funding. However, the signaling effects of other human capital factors reduce in each subsequent round thereby lowering the influence on the amount of funds raised in each respective round.

\subsection{Factoring in first round funding and its influence over subsequent rounds of funding}

The amount of funds raised in the first round is an important critical step for any new venture firm (Audretsch, 1995). The first round funding is an important signal for subsequent rounds of funding in two critical ways. Firstly, it provides the much-needed initial capital to test and build the new product/service. Many new ventures fail due to lack of initial support for their ideas and products (Kazanjian, 1998).

Secondly, a new venture firm is laced with great uncertainties (Hannan \& Freeman, 1984) and has very few external associations. The initial round of investment provides a unique opportunity for a firm to validate the capability of its founders, solutions and prospects of the firm (Baum et al., 2000). The signaling effect of the first round funding should be very strong (Hsu, 2004; Stuart et al., 1999) and enable subsequent rounds of funding for the new venture firm.

However, later rounds of funding do not hold the same significant value compared to the first round of funding (Kazanjian, 1998; Colombo \& Grilli, 
2007). The amount raised in the second round of funding should not influence the amount raised in the third round of funding.

H4a: Second round funding amount is influenced by the amount raised in the first round funding.

H4b: Third round funding amount is influenced by the amount raised in the first round funding, but not by the amount raised in the second round of funding.

\subsection{Funding rounds and attracting investors}

Funding rounds are important determinants that signal the prospect of a new venture firm; its quality reduces the potential uncertainty that arises due to information asymmetries. The credibility associated with each funding round provides a strong signaling mechanism to other investors (Davila et al., 2003). Since information asymmetries exist during the early stages, each successive round of funding closure helps reduce the uncertainties of the new venture firm to the labor market (Gompers \& Lerner, 1999) and future investors.

The factors that impact just one round of funding or at IPO are different than when looked a broad spectrum across the lifecycle of the firm (Zimmerman, 2008). Studying in a premier institution would be the distinctive variable that would provide the strongest signal to future investors for multiple reasons. First, founders who educated in premier institutions will be able to build innovative products and solutions that are capable of differentiating them from other competitors (Marvel \& Lumpkin, 2007). Second, the social network effect of studying in premier institutions should help with bridging gaps and introductions to investors at venture capital firms (D’Aveni, 1990). Beckman (2006) found that founders worked within the same industry are able to build relationships to important stakeholders thereby enhancing their capability in closing more funding rounds and attracting more investors.

H5a: New venture firms can close more funding rounds iffounders have completed education in a premier institution.
H5b: New venture firms can close more funding rounds if founders have more industry experience.

H6a: New venture firms can attract more investors if founders have completed education in a premier institution.

H6 b: New venture firms can attract more investors if founders have more industry experience.

\section{RESEARCH AIM}

The research aim is to disentangle the signaling effects of founders' human capital factors across multiple funding rounds, prove the non-persistence nature of signals across each subsequent round of funding, and emphasize impact of funds raised in the first round of funding.

\section{METHOD}

\subsection{Sample and data sources}

The hypotheses were tested using a sample of 156 Indian new venture firms. The firms established between January 1, 2010 and December 31, 2015 were included in this study. To make sure all startups had enough time to raise funds, startups founded after $12 / 31 / 2015$ were not included in the sample. On average, new venture firms in India in the specific sector of this study viz. e-commerce sector raise their first investment within eight months of establishment and close three rounds of funding with 27 months of establishment. In the sample, startups founded in December 2015 had enough time to raise multiple rounds of investment.

CrunchBase database, one of the most comprehensive open databases on information of new ventures, funding rounds and associated investments (Eugene \& Yuan, 2012), was used. CrunchBase specifically focuses on the information technology space and internet industry with data of over hundreds of investor firms (Block \& Sander, 2009). Furthermore, data were gathered from LinkedIn, company websites and news articles. The funding and associated information data from CrunchBase was validated by reviewing multiple news articles and company websites. LinkedIn database was specifically used 


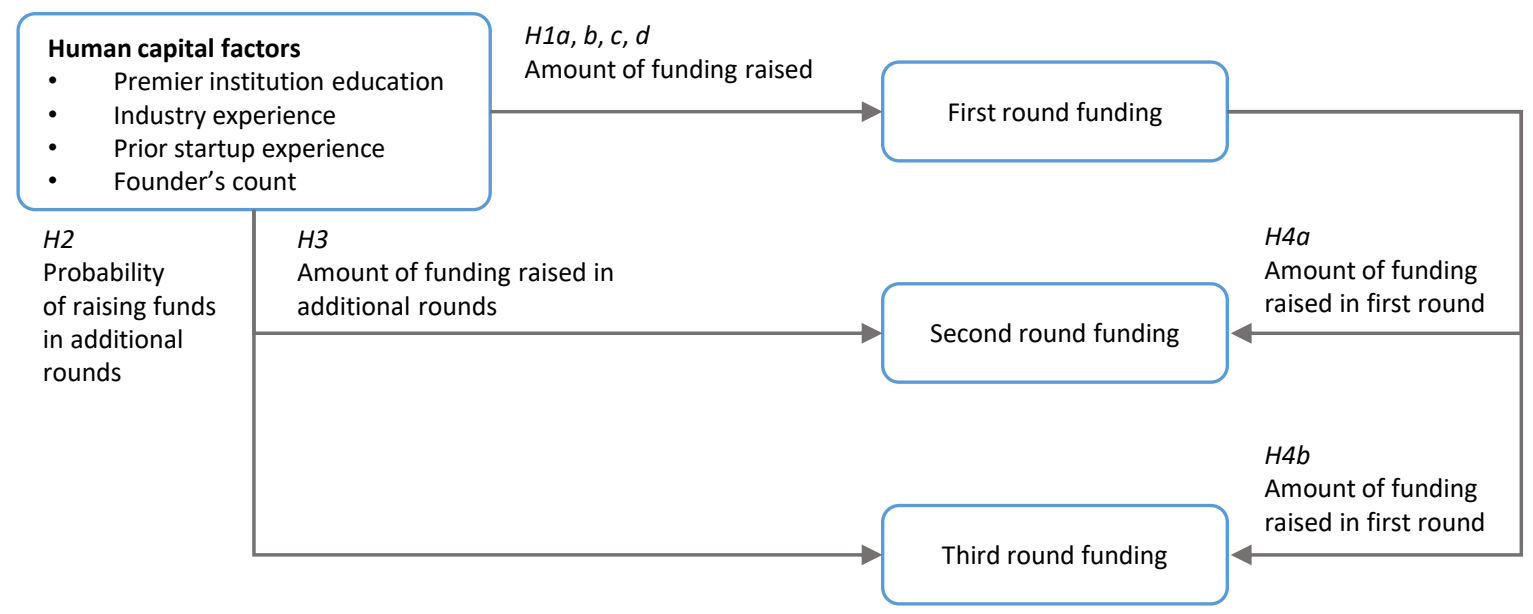

Figure 1. Signaling effects of human capital factors across multiple funding rounds and inter-funding round dependencies

to map founder details found on CrunchBase with data provided by founders on LinkedIn. In order to address legitimacy issues, LinkedIn data were used, since founders are particular about giving correct information about their education and past industry experience.

In India, between the years 2010 and 2014, the infusion of funds from venture capital and private equity firms increased from US $\$ 13$ million to US $\$ 1,818$ million (Thorton \& Assocham, 2016). Investment momentum in start-ups has increased rapidly with investment values increasing at a CAGR of more than 75\% between 2011 and 2015 .

This study focused on e-commerce industry with headquarters in India and founded between the year 2010 and 2015 to test independent effects of human capital, since all of them have similar founding and financing conditions. 341 startups met these criteria. After removing missing values for funding amount, the sample reduced to 156 startups.

\subsection{Measures}

Three different analyses were carried out in this paper:

1) likelihood of receiving funding using binary logit regression;

2) robustness check using linear regression to analyze effect of human capital on funding amount raised;
3) Poisson regression to see the effect of human capital on:

d) number of investors;

e) number of funding rounds.

This study analyzed the effect of human capital on likelihood of receiving more than a) one round of funding, b) two rounds of funding, c) three rounds of funding separately using binary logit regression. The dependent variable is a dichotomous variable indicating success or failure of the firm in getting each round of funding. Dependent variable for each round of funding carries 1 if firms close the funding round, otherwise 0 .

Robustness check using linear regression was performed for amount of funding raised in a) first round, b) second round, c) third round. Here the dependent variables are first round funding amount, second round funding amount and third round funding amount.

Effect of human capital in attracting investors and getting more funding rounds was determined by Poisson regression. Here the dependent variable is categorical - number of investors and number of funding rounds, respectively. To check whether first round funding amount influenced second round and third round funding amount, the Pearson correlation test was conducted among these variables. 


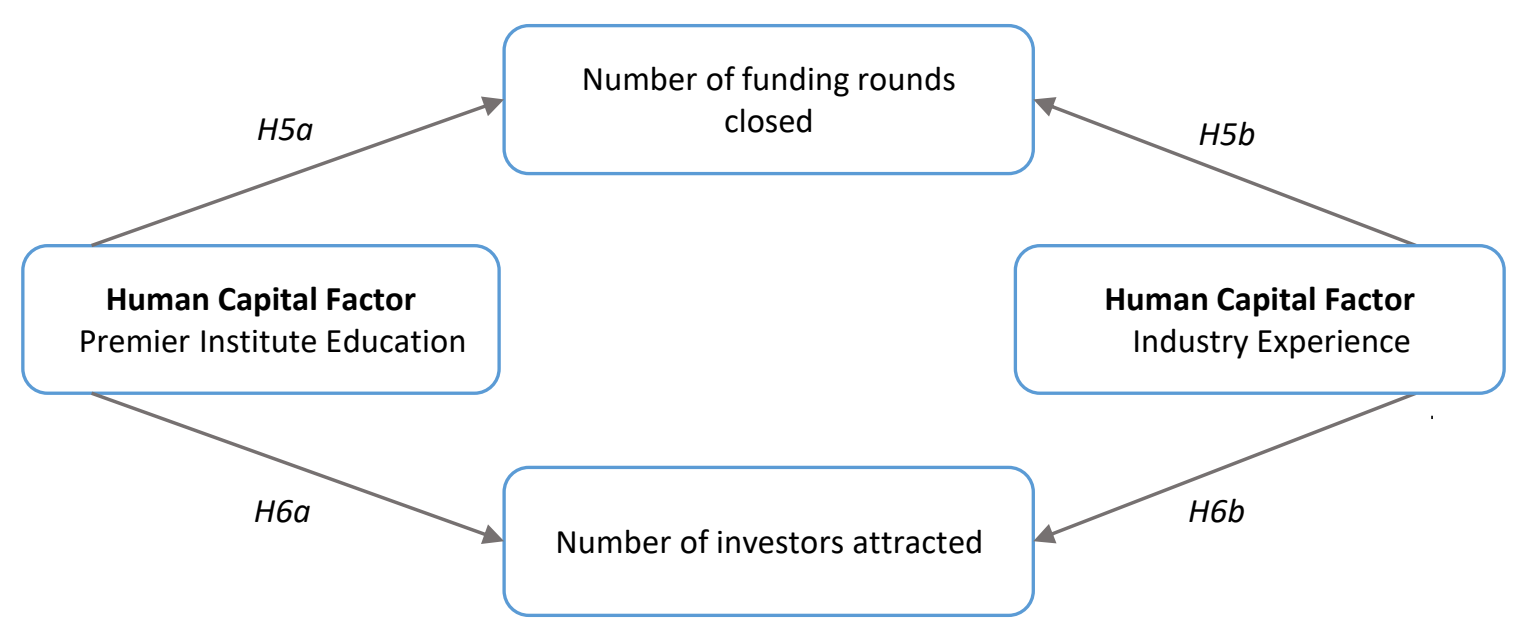

Figure 2. Number of funding rounds closed and number of investors attracted across multiple rounds of funding

\subsubsection{Dependent variables}

Funding raised - this dependent variable refers to the successful closure of funding by the new venture firm from angel investors and venture capital firms in a specific round. The likelihood of getting funding in each round is represented by the dichotomous variable and amount of funding raised in each round is represented by continuous variable with value in USD.

Funding rounds - the number of funding rounds that have been successfully closed by the new venture firm.
Investors - number of investors attracted by the new venture across all funding rounds.

\subsubsection{Independent variables}

\section{Premier institution education}

Founders educated from IIT and IIM, premier institutions in India were given a score of 1 . It is calculated by multiplying founders having premier institution education by number of founders. Also, founders who studied abroad carried a score of 1 .

Table 1. Model development criteria

\begin{tabular}{|c|c|c|}
\hline Variables & Reason for inclusion & Justification \\
\hline $\begin{array}{l}\text { Premier institution } \\
\text { education }\end{array}$ & $\begin{array}{l}\text { New variable, not included in previous } \\
\text { studies. CEOs that graduated from the top-20 } \\
\text { US universities were able to realize superior } \\
\text { performance (King et al., 2016). Individuals with } \\
\text { better degree credentials convey information } \\
\text { about differences in abilities, persistence and other } \\
\text { important traits (Becker, 1993) }\end{array}$ & $\begin{array}{l}\text { Highlights quality of education. Founders from } \\
\text { these institutions are generally more innovative } \\
\text { and could build products and services that have } \\
\text { more innovation radicalness and have sustained } \\
\text { competitive advantage against other competitors. } \\
\text { Strong social network. Investors look for new } \\
\text { venture firms that have strong competitive } \\
\text { advantages }\end{array}$ \\
\hline Industry experience & $\begin{array}{l}\text { Past industry experience provides a guiding post } \\
\text { for future performance of the new venture. Specific } \\
\text { knowledge of the industry helps mitigate some of } \\
\text { the risk by reducing the level of uncertainty related } \\
\text { to industry (Delmar \& Shane, 2006) }\end{array}$ & $\begin{array}{l}\text { Industry experience helps mitigate some of the } \\
\text { high risk associated with building a new product/ } \\
\text { service. Industry experience increases exposure } \\
\text { to current trends in the industry and reduces } \\
\text { technology uncertainty. Investors prefer certainty } \\
\text { in their investments, as it reduces their risk }\end{array}$ \\
\hline Prior startup experience & $\begin{array}{l}\text { Prior startup experience is considered an } \\
\text { important signal for future investors, as investors } \\
\text { can assess the capabilities of the founders in } \\
\text { similar situations and their performance in these } \\
\text { conditions (Hsu, 2007) }\end{array}$ & $\begin{array}{l}\text { Experiential knowledge with building a new } \\
\text { venture firm is distinct from industry experience. } \\
\text { Also, founders would have built connections with } \\
\text { various investors }\end{array}$ \\
\hline Founder's count & $\begin{array}{l}\text { New venture firms are founded by likeminded } \\
\text { individuals who have worked as employees } \\
\text { in large organizations and this leads to better } \\
\text { cohesion of the team at least during the initial } \\
\text { years }\end{array}$ & $\begin{array}{l}\text { Higher the founder count, higher the human } \\
\text { capital and cohesivity which leads to better } \\
\text { course of action. New venture firms with multiple } \\
\text { founders provide signals to investors about the } \\
\text { quality and more human capital which leads to } \\
\text { greater capital accumulations }\end{array}$ \\
\hline
\end{tabular}




\section{Industry experience}

Refers to the amount of time spent by the new venture firm founders in the e-commerce sector and internet industries. It is calculated as the number of years of industry experience of each founder multiplied by number of founders.

\section{Prior startup experience}

Refers to the total number of years of experience that the startup founders have gained at founding new venture firms before starting this new venture.

\section{Founder's count}

This variable refers to the total number of founders present in the new venture firm.

\subsubsection{Control variables}

This study controlled for industry and sector to capture the differences in the capability of firms in acquiring funds. Certain industries and sectors have variable funding needs, so it is important to control for both the industry and the sector.

The e-commerce industry/sector was chosen for several reasons. First, India has an online population of over 500 million users as of 2017 with a compound annual growth rate of $13 \%$, which is 4 times the global growth rate. The Indian e-commerce industry has been the greatest beneficiary of this growth (Kumar et al., 2012). Back in 2010, the e-commerce industry was a mere USD 5.9 billion market, but has seen rapid growth and was over USD 36 billion in the year 2017 and poised to grow over USD 150 billion in the next 5 years. From an investor's perspective, the e-commerce industry is the most lucrative market for investments with the potential to generate multi-bagger returns. This has led to a flood of global funds and investors to the Indian e-commerce industry. This was one of the main reasons to focus on this sector.

Secondly, in a growing e-commerce market, the main aim of the new entrants is to capture the market as much as possible. Amazon and other e-commerce firms in US had followed a similar strategy during the early days of the e-commerce boom and the need for expansion and the need to capture the market pushed these firms to raise multiple rounds of funding (Kshetri, 2007).

\section{RESULTS}

Table 2 includes descriptive statistics and the Pearson correlation among independent variables. Independent variables are not correlated. Variance inflation factor values were below 2.0.

Table 2. Descriptive statistics and Pearson correlations

\begin{tabular}{|c|c|c|c|c|c|c|}
\hline No. & Variable & Mean & $\begin{array}{c}\mathrm{SE} \\
\text { mean }\end{array}$ & 1 & 2 & 3 \\
\hline 1 & $\begin{array}{l}\text { Premier } \\
\text { institution } \\
\text { education }\end{array}$ & 0.96 & 0.09 & 1 & - & - \\
\hline 2 & $\begin{array}{l}\text { Industry } \\
\text { experience }\end{array}$ & 10.5 & 0.9 & .08 & 1 & - \\
\hline 3 & $\begin{array}{l}\text { Prior startup } \\
\text { experience }\end{array}$ & 3.31 & 0.49 & .04 & .06 & 1 \\
\hline 4 & Founder's count & 2.04 & 0.08 & $.28^{* * *}$ & $.46^{* * *}$ & $.18^{*}$ \\
\hline
\end{tabular}

Note: ${ }^{\star} p<.05,{ }^{\star *} p<.01,{ }^{\star * *} p<.001$.

Binary logistic regression was used to analyze the effect of human capital variables on closing each funding round successfully. Three different estimations were carried out for three rounds of funding viz. startups that raised more than a.one round of funding $b$. two rounds of funding $c$. three rounds of funding.

Dependent variable is dichotomous, value 1 if funding round is successful, otherwise 0 . The chances of receiving more than one round of funding are influenced only by founders' premier institution education and industry experience. Only premier institution education among other human capital variables influenced the outcome from more than two rounds of funding. Table 3 shows adjusted estimate of premier institution education in each round starting from more than one round with statistically significant estimate value of $.412^{* *}$, more than two rounds with $.396^{*}$ and more than three rounds with $.512^{\star}$. There were no other statistically significant values from other human capital variables under adjusted estimate. This shows that if founders have had education from premier institution likelihood of receiving funding increases. The goodness-of-fit tests were all greater than the significance level of 0.05 , not leaving enough evidence to conclude that the model does not fit the data. Robustness check was done with continuous dependent variable. 
Table 3. Estimates for raising funds across multiple rounds of funding using binary logit regression

\begin{tabular}{|c|c|c|c|c|}
\hline \multirow[b]{2}{*}{ Variable } & \multicolumn{2}{|c|}{ Unadjusted } & \multicolumn{2}{|c|}{ Adjusted } \\
\hline & Estimate & $\begin{array}{c}\text { Confidence } \\
\text { interval }\end{array}$ & Estimate & $\begin{array}{c}\text { Confidence } \\
\text { interval }\end{array}$ \\
\hline \multicolumn{5}{|c|}{ Estimates examining more than one round funding } \\
\hline Premier institution education & $.504 * *$ & $(.156, .852)$ & $.412 * *$ & $(.106, .717)$ \\
\hline Industry experience & .041 & $(.004, .077)$ & .027 & $(-.003, .057)$ \\
\hline Prior startup experience & .012 & $(-.048, .072)$ & .007 & $(-.045, .061)$ \\
\hline Founder's count & -.366 & $(-.826, .094)$ & .047 & $(-.268, .363)$ \\
\hline \multicolumn{5}{|c|}{ Estimates examining more than two rounds of funding } \\
\hline Premier institution education & $.451^{* *}$ & $(.124, .778)$ & $0.396^{*}$ & $(.046, .746)$ \\
\hline Industry experience & $.039 *$ & $(.006, .071)$ & 0.031 & $(-.005, .068)$ \\
\hline Prior startup experience & .001 & $(-.061, .063)$ & -0.01 & $(-.080, .060)$ \\
\hline Founder's count & .421 & $(.080, .762)$ & 0.169 & $(-.271,-1.51)$ \\
\hline \multicolumn{5}{|c|}{ Estimates examining more than three rounds of funding } \\
\hline Premier institution education & $.453^{*}$ & $(.028, .878)$ & $.512 *$ & $(.022,1.01)$ \\
\hline Industry experience & .034 & $(-.002, .072)$ & .046 & $(-.005, .098)$ \\
\hline Prior startup experience & -.007 & $(-.109, .094)$ & -.011 & $(-.135, .114)$ \\
\hline Founder's count & .228 & $(-.253, .710)$ & -.243 & $(-1.01, .52)$ \\
\hline
\end{tabular}

Note: ${ }^{*} p<.05,{ }^{* *} p<.01,{ }^{* * *} p<.001$.

Table 4 depicts the odds ratio for more than one round of funding. As seen from the table, the human capital factor premier institution education has a $p$-value of 0.005 and an odds ratio of 1.66. Also, the $p$-value for industry experience is 0.028 with and odds ratio of 1.04 . However, industry experience effect was seen only under unadjusted estimate.Poisson regression was used to analyze the effect on number of funding rounds. Dependent variable is a categorical variable viz. number of funding rounds. Result concluded that founder's premier institution education and their industry experience were influential in getting more funding rounds.

The $p$-value for premier institution education was .002 with coefficient value of .152 and $p$-value for industry experience was .011 with coefficient value of .013 for unadjusted estimation. Goodness-offit result proved that model fit the data.
Poisson regression was used to analyze the effect of human capital variables for attracting the number of investors. Only founders who have had premier institution education were able to attract more investors.

For premier institution education, both unadjusted and adjusted estimation $p$-values were less than .001 with coefficient values .224 and .214 , respectively. This result was also verified through goodness-of-fit result.

\subsection{Inter-funding round dependencies}

Table 6 shows that second round funding amount and third round funding amount correlated to first round funding amount. Second round and first round funding amount were highly correlated with Pearson correlation val-

Table 4. Odds ratio for more than one round of funding

\begin{tabular}{|c|c|c|c|c|c|c|c|}
\hline \multirow{2}{*}{ Predictor } & \multirow{2}{*}{ Coefficient } & \multirow{2}{*}{ SE coefficient } & \multirow{2}{*}{$\mathbf{Z}$} & \multirow{2}{*}{$\mathbf{P}$} & \multirow{2}{*}{$\begin{array}{l}\text { Odds } \\
\text { ratio }\end{array}$} & \multicolumn{2}{|c|}{$95 \%$} \\
\hline & & & & & & Lower & Upper \\
\hline Constant & -1.057 & 0.406 & -2.60 & 0.009 & - & - & - \\
\hline Premier institution education & 0.504 & 0.178 & 2.84 & 0.005 & 1.66 & 1.17 & 2.35 \\
\hline Industry experience & 0.041 & 0.019 & 2.20 & 0.028 & 1.04 & 1.00 & 1.08 \\
\hline Prior startup experience & 0.012 & 0.031 & 0.39 & 0.694 & 1.01 & 0.95 & 1.08 \\
\hline Founder's count & -0.366 & 0.235 & -1.56 & 0.119 & 0.69 & 0.44 & 1.10 \\
\hline
\end{tabular}



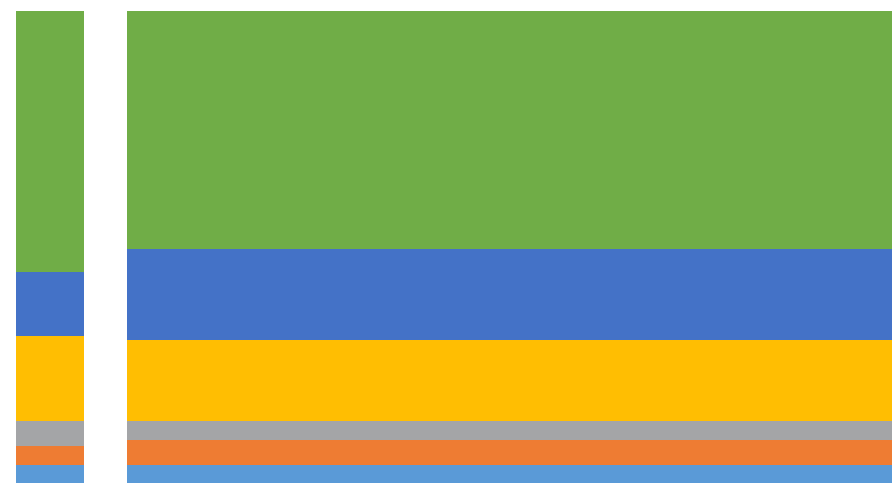

$\begin{array}{ll}\text { Premier } & \text { Industry } \\ \text { institution } & \text { experience }\end{array}$

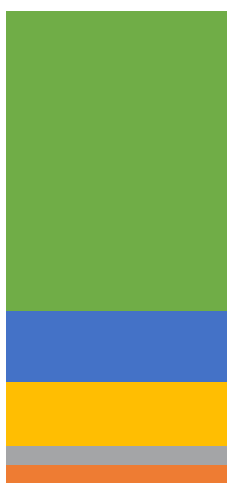

Prior startup experience

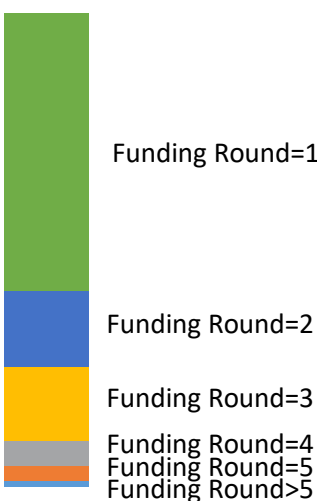

Founder' $s$ count

education

Figure 3. Mosaic plot showing relationships between number of funding rounds and human capital variables

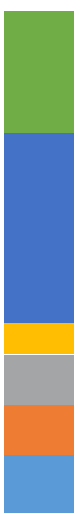

$$
\text { . }
$$

Premier institution education

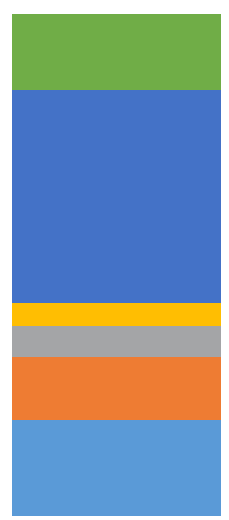

Prior startup experience

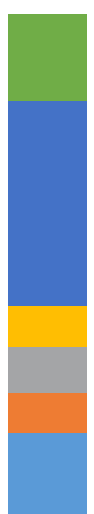

Investor's count $>5$

Investor's count $=5$

Investor's count $=4$ Investor's count $=3$ Investor's count $=2$ Investor's count $=1$

\section{Founder's count}

Figure 4. Mosaic plot showing relationships between number of investors and human capital variables

Table 5. Estimates for number of funding rounds and number of investors attracted using Poisson regression

\begin{tabular}{|c|c|c|c|c|}
\hline \multirow[b]{2}{*}{ Variables } & \multicolumn{2}{|c|}{ Unadjusted } & \multicolumn{2}{|c|}{ Adjusted } \\
\hline & Estimate & $\begin{array}{c}\text { Confidence } \\
\text { interval }\end{array}$ & Estimate & $\begin{array}{c}\text { Confidence } \\
\text { interval }\end{array}$ \\
\hline \multicolumn{5}{|c|}{ Estimates examining number of funding rounds } \\
\hline Premier institution education & $.150^{* *}$ & $(.058, .243)$ & $.152^{* *}$ & $(.055, .250)$ \\
\hline Industry experience & $.012^{* *}$ & $(.003, .020)$ & $.013^{*}$ & $(.003, .024)$ \\
\hline Prior startup experience & -.007 & $(-.028, .013)$ & -.009 & $(-.032, .013)$ \\
\hline Founder's count & .079 & $(-.023, .183)$ & -.037 & $(-.172, .097)$ \\
\hline \multicolumn{5}{|c|}{ Estimates examining number of investors attracted } \\
\hline Premier institution education & $.214^{* * *}$ & $(.116, .312)$ & $.224^{* * *}$ & $(.120, .328)$ \\
\hline Industry experience & .001 & $(-.007, .009)$ & -.002 & $(-.012, .006)$ \\
\hline Prior startup experience & -.014 & $(-.032, .003)$ & -.015 & $(-.034, .003)$ \\
\hline Founder's count & .017 & $(-.084, .120)$ & -.003 & $(-.134, .126)$ \\
\hline
\end{tabular}

Note: ${ }^{*} p<.05,{ }^{* *} p<.01,{ }^{* * *} p<.001$. 


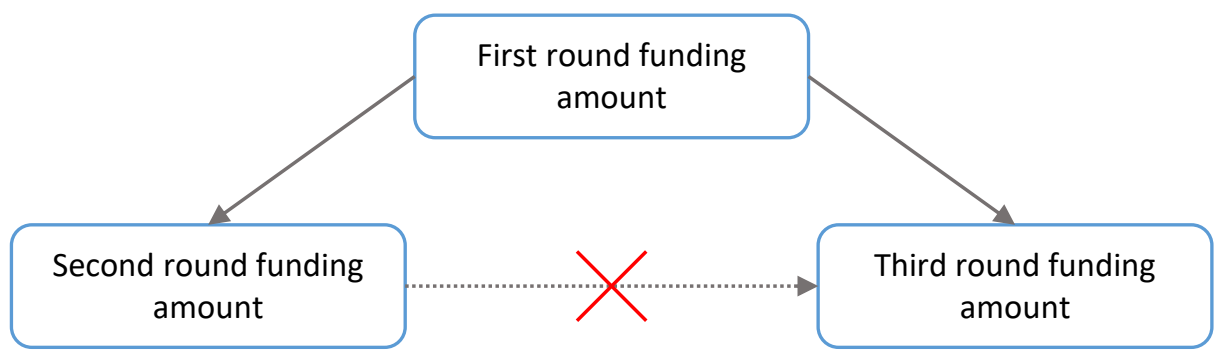

Figure 5. Inter-funding round dependencies

Table 6. Relationships between amounts raised in each funding round

\begin{tabular}{l|c|c}
\hline \multicolumn{1}{c|}{ Value of relationships } & Amount raised in 3rd round & Amount raised in 2nd round \\
\hline Amount raised in 1st round & $.46^{*}$ & .29 \\
\hline Amount raised in 2nd round & $.75^{* * *}$ \\
\hline
\end{tabular}

Note: ${ }^{*} p<.05,{ }^{* *} p<.01,{ }^{* * *} p<.001$.

ue of 0.749 . For third round funding amount and first round funding amount, Pearson correlation was medium $(0.455)$.

\subsection{Robustness checks}

In order to run robustness checks, multiple analysis of the data set to assess validity of results and rule out alternative explanations and mechanisms were carried out. Linear regression analysis on each round of funding was done to assess the impact of the human capi- tal factors on the amount of funding received by the startups. This gave an estimate of the impact of only startups that were successful in closing the round of funding. The results of the linear regression across each round of funding are listed in Table 7. Dependent variable was transformed using natural log. Effect of human capital variables on the amount of first round funding result showed that premier institution education, industry experience and prior startup experience of founding team had influence on the amount raised in the first round funding.

Table 7. Estimates for amount of funds raised across multiple rounds of funding using linear regression

\begin{tabular}{|c|c|c|c|c|}
\hline \multirow[b]{2}{*}{ Variable } & \multicolumn{2}{|c|}{ Unadjusted } & \multicolumn{2}{|c|}{ Adjusted } \\
\hline & Estimate & $\begin{array}{c}\text { Confidence } \\
\text { interval }\end{array}$ & Estimate & $\begin{array}{c}\text { Confidence } \\
\text { interval }\end{array}$ \\
\hline \multicolumn{5}{|c|}{ Estimates examining first round funding amount } \\
\hline Premier institution education & $.438^{* *}$ & $(.182, .694)$ & $.420^{* *}$ & $(.156, .683)$ \\
\hline Industry experience & $.035^{*}$ & $(.005, .065)$ & $.032 *$ & $(.001, .063)$ \\
\hline Prior startup experience & 0.127 & $(.050, .205)$ & $.104 * *$ & $(.027, .180)$ \\
\hline Founder's count & 0.094 & $(-.199, .389)$ & -0.225 & $(-.542, .092)$ \\
\hline \multicolumn{5}{|c|}{ Estimates examining second round funding amount } \\
\hline Premier institution education & $.541^{*}$ & $(.075,1.010)$ & $.565^{*}$ & $(.001,1.12)$ \\
\hline Industry experience & 0.017 & $(-.028, .063)$ & 0.012 & $(-.039, .065)$ \\
\hline Prior startup experience & 0.018 & $(-.083, .121)$ & 0.017 & $(-.086, .121)$ \\
\hline Founder's count & 0.276 & $(-.195, .748)$ & -0.073 & $(-.700, .552)$ \\
\hline \multicolumn{5}{|c|}{ Estimates examining third round funding amount } \\
\hline Premier institution education & 0.169 & $(-.940, .602)$ & -0.005 & $(-.987, .977)$ \\
\hline Industry experience & -0.041 & $(-.111, .027)$ & -0.039 & $(-.129, .050)$ \\
\hline Prior startup experience & 0.002 & $(-.259, .264)$ & 0.076 & $(-.247, .400)$ \\
\hline Founder's count & -0.263 & $(-.883, .356)$ & -0.154 & $(-1.099, .791)$ \\
\hline
\end{tabular}

Note: ${ }^{*} p<.05,{ }^{* *} p<.01,{ }^{* * *} p<.001$. 
Residual versus the fitted values

(response is 1st round funding amount ( $(\mathrm{n})$ )

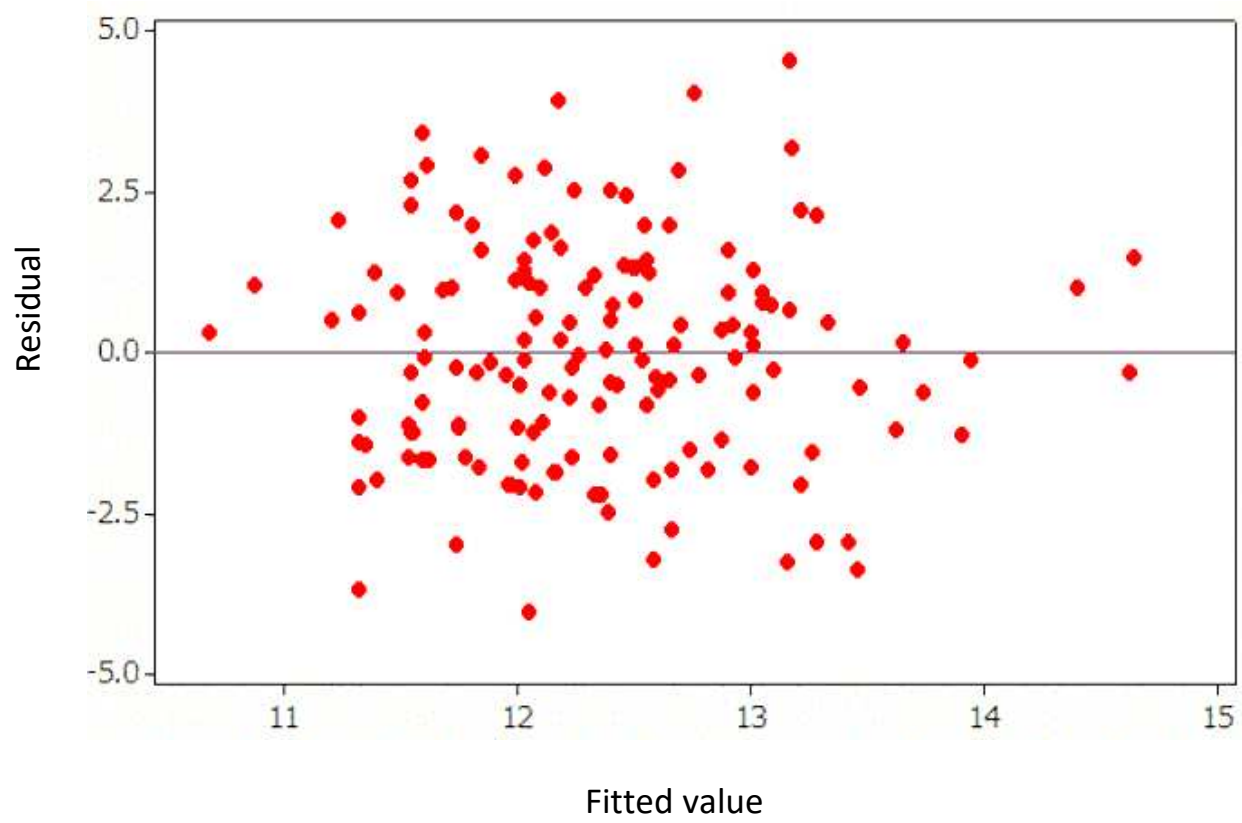

Figure 6. Residual vs fit plot for linear regression - first round funding amount vs human capital variables

Among these three variables, the premier institution education had highest estimate of .438 . The model fit well and it is shown in residual vs fitted plot (Figure 6).

For the second round, only premier institution education had significant impact on the second round funding amount raised. None of the other human capital variables had any influence. In third round of funding, the human capital variables had no effect on the amount of funding raised.

\section{DISCUSSION, IMPLICATIONS AND LIMITATIONS OF STUDY}

\subsection{Discussion}

The findings contribute to the existing literature by providing a novel view on the signaling effects of the human capital factors across multiple rounds of funding. The results are summarized below.
Hypotheses $1 a, 1 b, 1 c$ were supported. The significant predictors for raising first round amount were premier institution education $(\beta=0.42, p=0.002)$, industry experience $(\beta=0.032, p=0.044)$ and prior startup experience $(\beta=.104, p=0.008)$. Founder's count was not a significant predictor, hence, could not prove Hypothesis $1 d$.

Hypothesis 2 was supported. Signal emanating from premier institution persisted across subsequent rounds of funding. The premier institution education increased the odds of receiving more than one round of funding by 1.66 with $\beta=0.5$ and $p=0.005$, odds of receiving more than two rounds of funding by 1.49 with $\beta=0.39$ and $p=0.026$, odds of receiving more than three rounds of funding by 1.67 with $\beta=0.51$ and $p=0.041$. However, the significance reduced for each funding round. Other predictors were not significant.

Hypothesis 3 was supported. Founders with premier institution education raised more amounts of funding and the significance reduced in each subsequent round of funding. It was observed that premier institution education was highly signifi- 
cant for the first round with $\beta=0.42, p=0.002$ and continued to be slightly significant in the second round of funding $\beta=0.56, p=0.05$ and had no significance in the third round of funding. This demonstrates the diminishing effect of the premier institution education across each subsequent round of funding. As stated in Hypothesis 1 , the industry experience and prior startup experience were significant only during the first round of funding, but had no significance in the second and third round of funding illustrating the diminishing value of these variables.

Hypotheses $4 a$ and $4 b$ were supported. The amount raised in the second round of funding was highly influenced by the amount raised in the first round of funding with Pearson coefficient $=0.749$ and $p$-value $<0.001$. The amount raised in the third round of funding was also influenced by the amount raised in the first round of funding, but with less effect. Pearson coefficient was $0.455, p=0.033$. The amount raised in the third round of funding was not influenced by the amount raised in the second round of funding.

Hypotheses $5 a$ and $5 b$ were supported. Premier institution education attracted more number of funding rounds with $\beta=0.15$ and $p=0.002$. For industry experience, the values were $\beta=0.01$ and $p=0.011$.
Hypothesis $6 a$ was supported. Premier institution educated attracted number of investors with $\beta=0.22$ and $p<0.001$. Hypothesis $6 b$ was not supported.

The findings have important practical and research implications for practitioners and academics in the area of funding acquisition for new venture firms.

\subsection{Implications for practitioners}

This study analyzed the effect of the first round of funding and its correlation to future rounds of funding. This study found that the amount raised in first round was highly correlated to the amounts raised in the second round of funding and the third round of funding. Investors provide an overarching importance to the amount of funds raised in the first round. The higher the amount of funds raised by a new venture firm in the first round, higher the likelihood for the firm to raise larger amounts of funds in the subsequent rounds. This provides an interesting proposition for practitioners viz. the new venture firms; they should attempt to raise a large amount of funding in their first round irrespective of the need for the large amount as this positively influences future rounds of funding.

This study also concluded that new venture firm founders should team with other founders that have

Table 8. Linkage of proposed method and results

\begin{tabular}{|c|c|c|}
\hline Result steps & Influencing factors & $\begin{array}{l}\text { Link to proposed } \\
\text { method }\end{array}$ \\
\hline $\begin{array}{l}\text { Table } 3 \text {. Estimates examining more } \\
\text { than one round, two rounds and three } \\
\text { rounds of funding using binary logit } \\
\text { regression }\end{array}$ & $\begin{array}{l}\text { Likelihood of receiving more than one, two and three } \\
\text { rounds of funding is influenced only by premier institution } \\
\text { education. Adjusted estimate of premier institution } \\
\text { education }=0.412^{* *} \text { for more than one round, } 0.396^{*} \text { for } \\
\text { more than two rounds, } 0.512^{*} \text { for more than three rounds of } \\
\text { funding }\end{array}$ & Hypothesis 2 \\
\hline $\begin{array}{l}\text { Table } 5 \text {. Estimates for number of } \\
\text { funding rounds and number of } \\
\text { investors attracted using Poisson } \\
\text { regression }\end{array}$ & $\begin{array}{l}\text { Premier institution education and industry experience } \\
\text { attracts more number of funding rounds }(5 \mathrm{a}, 5 \mathrm{~b}) \text {. Adjusted } \\
\text { estimate for premier institution education }=0.152^{* *} \text {, industry } \\
\text { experience }=0.013^{*} \text {. Premier institution education attracts } \\
\text { more number of investors }(6 \mathrm{a}) \text { : adjusted estimate }=0.224^{* * *}\end{array}$ & Hypotheses 5a, 5b, 6a \\
\hline \multirow{2}{*}{$\begin{array}{l}\text { Table } 6 . \text { Relationships between } \\
\text { amounts raised in each funding round }\end{array}$} & $\begin{array}{l}\text { Hypotheses } 4 \text { a: second round funding amount is influenced } \\
\text { by the amount raised in the first round funding. Pearson } \\
\text { correlation }=0.75^{* * *}\end{array}$ & \multirow[b]{2}{*}{ Hypotheses 4a, 4b } \\
\hline & $\begin{array}{l}\text { Hypothesis } 4 \text { b: third round funding amount is influenced } \\
\text { by the amount raised in the first round funding, but not by } \\
\text { the amount raised in the second round of funding. Pearson } \\
\text { correlation }=0.46^{*}\end{array}$ & \\
\hline \multirow{2}{*}{$\begin{array}{l}\text { Table } 7 \text {. Estimates for amount of } \\
\text { funds raised across multiple rounds of } \\
\text { funding using linear regression }\end{array}$} & $\begin{array}{l}\text { Adjusted estimate for premier, industry and prior startup } \\
\text { experience }=0.420^{* * *}, 0.032^{*}, 0.104^{* *}\end{array}$ & Hypotheses 1a, 1b, 1c \\
\hline & $\begin{array}{l}\text { Adjusted estimate for premier institution education }=0.565^{*} \\
\text { for second round of funding }\end{array}$ & Hypothesis 3 \\
\hline
\end{tabular}


education from premier institutions. Investors are attracted and provide funding to venture firms with founders from premier institutions. Impact of the premier institute is understandable and justified as founders from premier institutins could build products and services that create a distinct advantage over existing products and services and have more innovation radicalness.

\subsection{Implications for researchers}

This paper disentangled the effects of various human capital factors across three funding rounds as opposed to existing literature that focused only one stage first funding round or IPO stage. It proved varying impact of each of the human capital factors at different stages of the startup and gradual diminishing effect followed by zero effect as the startup raised each consecutive round of funding. This echoed with Hoenen et al. (2014) who studied the impact of patents across early rounds of funding. The only factor that continued to have sustained impact across the three rounds of funding was the education from premier institutions.
Secondly, previous research only focused on the education level completed by the founders, but did not look at the quality of the education as determined by the education completed from a premier institution (Klotz et al., 2014). This was a substantial finding of the research, which helped unravel the unique dimension of quality of education and its impact on new venture firms. This study found that the premier institution human capital factor was the unique and the only factor that sustained across the first three rounds of funding.

\subsection{Limitations and future research}

To conclude, this study has limitations that open the scope for further research. First, distinguish equity based funding from debt based funding of startups as the characteristics of the funds vary between the two. Second, look at the impact of patents and its relation to each funding round for startups with founders from premier institutions. Third, distinguish types of investors, i.e. distinction among angel investors, early stage venture firms and mid-stage venture firms and study the signaling effect from each of them separately.

\section{CONCLUSION}

The early rounds of funding for new venture firms are fraught with complexities and uncertainties. This study has disentangled the signaling effects of the human capital factors across three funding rounds and proved the diminishing value of signals across each subsequent round of funding as investors look for other cues to make a funding decision. This would be a new contribution to the study of signaling and human capital theory. This study unraveled the importance of quality of education and the significant importance given to it by investors across multiple rounds of funding. Founders graduating from premier educational institutions were able to attract more investors and close more funding rounds. It also highlighted the importance of the amount raised in the first round of funding and the leverage it provided to future rounds of funding. Irrespective of the need for larger amounts, founders need to strive and raise more funds in their first round. Overall, the findings demonstrated the various funding acquisitions drivers and their diminishing impact during the early stages of funding for new venture firms.

\section{REFERENCES}

1. Amason, A. C., Shrader, R.

C., \& Tompson, G. H. (2006).

Newness and novelty: Relating top management team composition to new venture performance. Journal of Business Venturing, 21(1), 125148. https://doi.org/10.1016/j. jbusvent.2005.04.008
2. Audretsch, D. B. (1995). Innovation, growth and survival. International journal of industrial organization, 13(4), 441-457. https://doi.org/10.1016/01677187(95)00499-8

3. Baum, J. A., Calabrese, T., \& Silverman, B. S. (2000).

\author{
Don't go it alone: Alliance \\ network composition and \\ startups' performance in \\ Canadian biotechnology. \\ Strategic management journal, \\ 21(3), 267-294. https://doi. \\ org/10.1002/(SICI) 1097 - \\ 0266(200003)21:3<267::AID- \\ $\mathrm{SMJ} 89>3.0 . \mathrm{CO} ; 2-8$
}


4. Baum, J. A., \& Silverman, B. S. (2004). Picking winners or building them? Alliance, intellectual, and human capital as selection criteria in venture financing and performance of biotechnology startups. Journal of business venturing, 19(3), 411-436. https://doi.org/10.1016/S08839026(03)00038-7

5. Barney, J. B., Busenitz, L. W., Fiet, J. O., \& Moesel, D. D. (1996). New venture teams' assessment of learning assistance from venture capital firms. Journal of Business Venturing, 11(4), 257-272. https://doi.org/10.1016/08839026(95)00011-9

6. Beckman, C. M. (2006). The influence of founding team company affiliations on firm behavior. Academy of Management Journal, 49(4), 741-758. https://doi.org/10.5465/ amj.2006.22083030

7. Becker-Blease, J. R., \& Sohl, J. E. (2015). New venture legitimacy: the conditions for angel investors. Small Business Economics, 45(4), 735-749. https://doi.org/10.1007/ s11187-015-9668-7

8. Block, J., \& Sandner, P. (2009). What is the effect of the financial crisis on venture capital financing? Empirical evidence from US Internet start-ups. Venture Capital, 11(4), 295-309. https://dx.doi. org/10.2139/ssrn.1373723

9. Burton, M. D., Sørensen, J. B., \& Beckman, C. M. (2002). Coming from good stock: Career histories and new venture formation. In Social structure and organizations revisited (pp. 229-262). Emerald Group Publishing Limited.

10. Busenitz, L. W., Fiet, J. O., \& Moesel, D. D. (2005). Signaling in Venture Capitalist - New Venture Team Funding Decisions: Does it Indicate Long-Term Venture Outcomes? Entrepreneurship Theory and Practice, 29(1), 1-12. https://doi.org/10.1111/j.15406520.2005.00066.x

11. Cassar, G. (2014). Industry and startup experience on entrepreneur forecast performance in new firms. Journal of Business
Venturing, 29(1), 137-151. https://doi.org/10.1016/j.jbusvent.2012.10.002

12. Certo, S. T. (2003). Influencing initial public offering investors with prestige: Signaling with board structures. Academy of management review, 28(3), 432446. https://doi.org/10.5465/ amr.2003.10196754

13. Chevalier, J., \& Ellison, G. (1999). Career concerns of mutual fund managers. The Quarterly Journal of Economics, 114(2), 389-432. https://doi. org/10.1162/003355399556034

14. Clement, W. (1975). Inequality of access: characteristics of the Canadian corporate elite. Canadian Review of Sociology/ Revue canadienne de sociologie, 12(1), 33-52. https://doi. org/10.1111/j.1755-618X.1975. tb00025.x

15. Colombo, M. G., \& Grilli, L. (2007). Funding gaps? Access to bank loans by high-tech start-ups. Small Business Economics, 29(1-2), 25-46. https://doi.org/10.1007/ s11187-005-4067-0

16. Connelly, B. L., Certo, S. T., Ireland, R. D., \& Reutzel, C. R. (2011). Signaling theory: A review and assessment. Journal of management, 37(1), 39-67. https://doi. org/10.1177/0149206310388419

17. Cooper, A. C., Gimeno-Gascon, F. J., \& Woo, C. Y. (1994). Initial human and financial capital as predictors of new venture performance. Journal of business venturing, 9(5), 371-395. https://doi.org/10.1016/08839026(94)90013-2

18. D’Aveni, R. A. (1990). Top managerial prestige and organizational bankruptcy. Organization Science, 1(2), 121142. https://doi.org/10.1287/ orsc.1.2.121

19. Davila, A., Foster, G., \& Gupta, M. (2003). Staging venture capital: empirical evidence on the differential roles of early versus late rounds. Retrieved from http:// citeseerx.ist.psu.edu/viewdoc/ summary?doi=10.1.1.202.3427
20. Delmar, F., \& Shane, S. (2006).

Does experience matter? The effect of founding team experience on the survival and sales of newly founded ventures. Strategic Organization, 4(3), 215-247. https://doi. org/10.1177/1476127006066596

21. Eugene, L. Y., \& Yuan, S. T. D. (2012, August). Where's the money? The social behavior of investors in facebook's small world. In Proceedings of the 2012 International Conference on Advances in Social Networks Analysis and Mining (ASONAM 2012) (pp. 158-162). IEEE Computer Society. https://doi. org/10.1109/ASONAM.2012.36

22. Gompers, P. A. (1995). Optimal investment, monitoring, and the staging of venture capital. The Journal of Finance, 50(5), 1461-1489. https://doi. org/10.1111/j.1540-6261.1995. tb05185.x

23. Gompers, P. A., \& Lerner, J. (1999). What drives venture capital fundraising? (No. w6906). National bureau of economic research. https://doi.org/10.3386/w6906

24. Grant Thornton, Assocham (2016). Startups India - an Overview. New Delhi: Grant Thornton India LLP). Assocham, The Associated Chambers of Commerce of India.

25. Hannan, M. T., \& Freeman, J. (1984). Structural inertia and organizational change. American sociological review, 49(2), 149-164. https://doi.org/10.2307/2095567

26. Henry, O., \& Ferry, M. (2017). When Cracking the JEE is not Enough. Processes of Elimination and Differentiation, from Entry to Placement, in the Indian Institutes of Technology (IITs). South Asia Multidisciplinary Academic Journal, 15. Retrieved from https://journals.openedition.org/ samaj/4291

27. Hoenen, S., Kolympiris, C., Schoenmakers, W., \& Kalaitzandonakes, N. (2014). The diminishing signaling value of patents between early rounds of 
venture capital financing. Research Policy, 43(6), 956-989. https://doi. org/10.1016/j.respol.2014.01.006

28. Huang, M. H. (2012). Opening the black box of QS World University Rankings. Research Evaluation, 21(1), 71-78. https:// doi.org/10.1093/reseval/rvr003

29. Hsu, D. H. (2004). What do entrepreneurs pay for venture capital affiliation? The Journal of Finance, 59(4), 1805-1844. https://doi.org/10.1111/j.15406261.2004.00680.x

30. Hsu, D. H. (2007). Experienced entrepreneurial founders, organizational capital, and venture capital funding. Research Policy, 36(5), 722-741. https://doi. org/10.1016/j.respol.2007.02.022

31. Kazanjian, R. K. (1988). Relation of dominant problems to stages of growth in technology-based new ventures. Academy of management journal, 31(2), 257-279. https:// doi.org/10.5465/256548

32. King, T., Srivastav, A., \& Williams, J. (2016). What's in an education? Implications of CEO education for bank performance. Journal of Corporate Finance, 37, 287-308. https://doi.org/10.1016/j.jcorpfin.2016.01.003

33. Kirzner, I. M. (1997). Entrepreneurial discovery and the competitive market process: An Austrian approach. Journal of economic Literature, 35(1), 60-85. Retrieved from https://www.jstor. org/stable $/ 2729693$ ?seq=1\#page_ scan_tab_contents

34. Klepper, S. (2001). Employee startups in high-tech industries. Industrial and corporate change, 10(3), 639-674. https://doi. org/10.1093/icc/10.3.639

35. Klotz, A. C., Hmieleski, K. M., Bradley, B. H., \& Busenitz, L. W. (2014). New venture teams: A review of the literature and roadmap for future research. Journal of management, 40(1), 226-255. https://doi. org/10.1177/0149206313493325

36. Krishna, V. V., \& Chandra, N. (2011). Knowledge production and knowledge transfer: A study of two Indian institutes of technology (IIT Madras and IIT Bombay). In Academic Entrepreneurship in Asia: The Role and Impact of Universities in National Innovation Systems (pp. 254-288).

37. Kshetri, N. (2007). Barriers to e-commerce and competitive business models in developing countries: A case study. Electronic commerce research and applications, 6(4), 443452. https://doi.org/10.1016/j. elerap.2007.02.004

38. Maidique, M. A. (1985). Key success factors in high technology ventures. Innovation \& Entrepreneurship Institute, University of Miami.

39. Marvel, M. R., \& Lumpkin, G. T. (2007). Technology entrepreneurs' human capital and its effects on innovation radicalness. Entrepreneurship Theory and Practice, 31(6), 807-828. https://doi.org/10.1111/j.15406520.2007.00209.x

40. Miller, D., Xu, X., \& Mehrotra, V. (2015). When is human capital a valuable resource? The performance effects of Ivy League selection among celebrated CEOs. Strategic Management Journal, 36(6), 930-944. https://doi. org/10.1002/smj.2251

41. Kumar, M., Sareen, M., \& Barquissau, E. (2012). Relationship between types of trust and level of adoption of Internet banking. Problems and Perspectives in Management, 10(1), 82-92. Retrieved from https://businessperspectives.org/pdfproxy. php?item_id:4455

42. Paige, R. M., Fry, G. W., Stallman, E., Jon, J. E., \& Josić, J. (2010). Beyond immediate impact: Study abroad for global engagement (SAGE). Report submitted to the Title VI International Research and Studies Program, US Department of Education, Washington, DC.

43. Rédis, J. (2010). ICT start-ups venture capital and funding. Problems and Perspectives in Management, 8, 30-37. Retrieved from https://businessperspectives. org/images/pdf/applications/ publishing/templates/article/as-
sets/3744/PPM_EN_2010_4_SI_ Redis.pdf

44. Reuber, A. R., \& Fischer, E. M (1994). Entrepreneurs' experience, expertise, and the performance of technology-based firms. IEEE Transactions on engineering management, 41(4), 365-374. https://doi.org/10.1109/17.364560

45. Schmidt, S., \& Pardo, M. (2017). The contribution of study abroad to human capital formation. The Journal of Higher Education, 88(1), 135-157. https://doi.org/10.1080/0 0221546.2016.1243951

46. Stinchcombe, A. L., \& March, J. G. (1965). Social structure and organizations. Handbook of organizations, 7, 142-193.

47. Stuart, T. E., Hoang, H., \& Hybels, R. C. (1999). Interorganizational endorsements and the performance of entrepreneurial ventures. Administrative science quarterly, 44(2), 315-349. https:// doi.org/10.2307/2666998

48. Subramanian, A. (2015). Making merit: The Indian Institutes of Technology and the social life of caste. Comparative Studies in Society and History, 57(2), 291-322. https://doi.org/10.1017/ S0010417515000043

49. Tapper, T., \& Filippakou, O. (2009). The world-class league tables and the sustaining of international reputations in higher education. Journal of Higher Education Policy and Management, 31(1), 55-66. https://doi. org/10.1080/13600800802383091

50. Zimmerman, M. A. (2008). The influence of top management team heterogeneity on the capital raised through an initial public offering. Entrepreneurship Theory and Practice, 32(3), 391-414. https://doi.org/10.1111/j.15406520.2008.00233.x 